\title{
Examination of Turkish extreme athletes' personality traits in terms of gender and some demographic factors
}

\author{
Merve Ceylan ${ }^{1}$ \\ Ersin Altıparmak ${ }^{2}$ \\ Fahri Akçakoyun ${ }^{3}$
}

\begin{abstract}
The present study was conducted for the purpose of examining the personality traits of extreme athletes. In line with this purpose a total of 227 extreme athletes, as 86 female and 141 male athletes selected through judgment sampling, that either actively compete or trains to compete in any of the branches of snowboarding, snowkiting, kitesurfing, windsurfing, river kayaking, mountain biking, free diving, paragliding and rafting were included within the sample group of the study. Questionnaire applications were carried out in extreme sports facilities throughout the country.

Within the scope of the study, an 85-item short form of the Five Factor Personality Scale developed by Somer, Korkmaz and Tatar was used as the data collection tool. Data analysis was carried out by means of the SPSS 16.0 software and the percentages frequencies, mean, standard deviation and to find the differences between the sexes "independent $t$ " test were calculated.

Examining the obtained results showed that the male athletes have higher extravertion level from female athletes $(\mathrm{p}<0.05)$. This finding obtained in our study suggest that, in an essentially male-dominant society, the higher level of pressure women are subjected to in social, economic, cultural and psychological terms and the difficulties and pressure they experience in the working life are significant factors for women to be more introvert.
\end{abstract}

Keywords: Extreme Sports; Extreme Athletes; Personality

\section{Introduction}

The modern way of life and tendencies of modern sports have caused a considerable increase in the participation to extreme sports and adventurous activities, particularly young followers of which increase day by day and which usually require speed, height, high levels of physical effort, balance, quick decision making ability and special equipments (Şimşek, 2011).

Having maintained their popularity ever since the 1960's in developed countries, extreme sports may cause injuries with severe consequences or even death. Still, with the sense of

${ }^{1}$ Dr., Mugla Sitk1 Koçman University, Faculty of Sports Science, Physical Education And Sport, merveceylan@ymail.com

2Dr., Ege University, Physical Education And Sport Schools, Psychosocial Fields in Sports, ersin.altiparmak@ege.edu.tr ${ }^{3}$ Dr., Mugla Sitkı Koçman University, Faculty of Sports Science, Recreation, afahri@,mu.edu.tr 
Ceylan, M., Altıparmak, E., \& Akçakoyun, F. (2015). Examination of Turkish extreme athletes' personality traits in terms of gender and some demographic factors. International Journal of Human Sciences, 12(2), 502-512. doi:10.14687/ijhs.v12i2.3310

excitement they offer and with their qualities of risk taking, desire to succeed, extraversion, unusualness, fun, contest and adventure seeking, extreme sports may attract the interest of masses that are tired of the difficulties introduced by the social life and that have to live a stressful life. Extreme sports may be partially defined as a new form of sports, or a mean to obtain a unique and personal pleasure in the form of unusual personal achievement. In essence, extreme sports are individual branches of sports that -in contrast with team sports- include certain dangers, unusual rules or techniques (Şimşek, 2010).

Studies conducted on the participants of risk-involving sports indicate that these people have two common traits. These are, in general, looking for excitement and high levels of self-efficacy. It is observed that these two traits are the main factors that affect participation to risk-involving sports and entertainment activities.

Although participation to risk-involving sports grows day by day and increasing number of studies are conducted on these participants, the number of studies conducted on the athletes that are involved in these sports as "contestants" is limited. Taking these sports a step further and becoming a contestant is not possible for all extreme sports participants due to the high risk factor involved and lack of time. Due to this reason, our study does not focus on the general extreme sports participants but extreme sports contestants.

Extreme sports that develop rather rapidly in Turkey and the fact that interest for these sports grows everyday also put the related federations into action and enabled them to initiate the works to raise athletes. Considering from this perspective, conducting further studies on extreme sports and extreme athletes becomes a necessity. The present study is considered to be important in terms of being a source for the future studies to be conducted and for the creation of the literature concerned with extreme sports.

\section{Material and Method}

Within the scope of the study, an 85-item short form of the Five Factor Personality Scale developed by Somer, Korkmaz and Tatar (2004) was used as the data collection tool. In the short form of the Five Factor Personality Scale, scores concerning five basic factors (Extraversion Cronbach's alpha .82, Agreeableness- Cronbach's alpha .81, Conscientiousness- Cronbach's alpha .67, Emotional Instability- Cronbach's alpha .86 and Openness to Experience- Cronbach's alpha .71) are obtained for each participant.

The sample of the study consists of extreme athletes -either actively participating in contests or training to get ready- who train in facilities in Turkey where extreme sports activities are carried 
Ceylan, M., Altıparmak, E., \& Akçakoyun, F. (2015). Examination of 'Turkish extreme athletes' personality traits in terms of gender and some demographic factors. International Journal of Human Sciences, 12(2), 502-512. doi:10.14687/ijhs.v12i2.3310

out (kitesurfing, windsurfing, paragliding, snowboard, snowkiting, rock climbing, rafting, river kayaking and mountain biking) in order to get ready for contests. 227 athletes, a total of 86 women and 141 men, were participated in the research. The data were collected in a period of 11 months, through face to face interviews conducted with the participants. Data analysis was carried out by means of the SPSS 16.0 software. The percentages, frequencies, mean, standard deviation and to find the differences between the sexes "independent samples t- test" were calculated.

\section{Findings}

Table 1: Athletes' distribution by gender

\begin{tabular}{|l|c|l|}
\hline Gender & $\mathbf{N}$ & $\mathbf{\%}$ \\
\hline Female & 86 & 37.9 \\
\hline Male & 141 & 62.1 \\
\hline TOTAL & $\mathbf{2 2 7}$ & $\mathbf{1 0 0}$ \\
\hline
\end{tabular}

Examining the gender distribution of the sample group shows that while $37.9 \%$ (86) of the participants are females the remaining $62.1 \%(141)$ are males.

Table 2: Athletes distribution by marital status

\begin{tabular}{|l|c|l|}
\hline Marital status & $\mathbf{N}$ & $\mathbf{\%}$ \\
\hline Married & 64 & 28.2 \\
\hline Single & 118 & 52.0 \\
\hline Divorced & 45 & 19.8 \\
\hline TOTAL & $\mathbf{2 2 7}$ & $\mathbf{1 0 0}$ \\
\hline
\end{tabular}

Examining the distribution of the sample group by marital status shows that while single participants constitute $52.0 \%$ (118) of the group, married and divorced participants respectively constitute $28.2 \%$ (64) and $19.8 \%$ (45). 
Ceylan, M., Altıparmak, E., \& Akçakoyun, F. (2015). Examination of Turkish extreme athletes' personality traits in terms of gender and some demographic factors. International Journal of Human Sciences, 12(2), 502-512. doi:10.14687/ijhs.v12i2.3310

Table 3: Athletes' distribution based on the media they use to follow news related with their respective branches

\begin{tabular}{|l|l|l|}
\hline Media & $\mathbf{N}$ & $\mathbf{\%}$ \\
\hline Book & 5 & 2.2 \\
\hline Journal & 26 & 11.4 \\
\hline Newspaper & 2 & .9 \\
\hline TV & 59 & 26.0 \\
\hline The Internet & 135 & 59.5 \\
\hline TOTAL & $\mathbf{2 2 7}$ & $\mathbf{1 0 0}$ \\
\hline
\end{tabular}

Examining the sample group's distribution on the basis of mass media they use to follow news concerning their branches showed that while $2.2 \%$ (5) of the participants consult books, $11.4 \%$ (26) follow journals, $0.9 \%$ (2) follow newspapers, $26.0 \%$ (59) watches TV (59) and 59.5\% (135) use the internet.

Table 4: Athletes' distribution by their educational status

\begin{tabular}{|l|l|l|}
\hline \multicolumn{1}{|c|}{ Educational status } & $\mathbf{N}$ & $\mathbf{\%}$ \\
\hline Literate & 1 & .4 \\
\hline Primary school graduate & 7 & 3.1 \\
\hline High school graduate & 65 & 28.6 \\
\hline Associate / Bachelor's degree & 118 & 52.0 \\
\hline Postgraduate (Masters - Doctor's degree) & 36 & 15.9 \\
\hline TOTAL & $\mathbf{2 2 7}$ & $\mathbf{1 0 0}$ \\
\hline
\end{tabular}

Examining the distribution of the sample group by educational status shows that while $0.4 \%$ (1) of the participants was merely literate, 3.1\% (7) were primary school graduates, $28.6 \%$ (65) were high school graduates, $52.0 \%$ (118) have associates or bachelor's degree and 15.9\% (36) have masters or doctors' degree. 
Ceylan, M., Altıparmak, E., \& Akçakoyun, F. (2015). Examination of Turkish extreme athletes' personality traits in terms of gender and some demographic factors. International Journal of Human Sciences, 12(2), 502-512. doi:10.14687/ijhs.v12i2.3310

Table 5: Athletes' distribution by job

\begin{tabular}{|l|l|l|}
\hline Profession & $\mathbf{N}$ & $\mathbf{9}$ \\
\hline Housewife & 2 & .9 \\
\hline Worker & 8 & 3.5 \\
\hline Civil servant & 33 & 14.5 \\
\hline Retired & 8 & 3.5 \\
\hline Student & 56 & 24.7 \\
\hline Artisan & 36 & 15.9 \\
\hline Self - employed & 37 & 16.3 \\
\hline Manager & 27 & 11.9 \\
\hline Others & 20 & 8.8 \\
\hline TOTAL & $\mathbf{2 2 7}$ & $\mathbf{1 0 0}$ \\
\hline
\end{tabular}

Examining the distribution of the sample group by profession shows that while $0,9 \%$ of the participants was housewives, $3.5 \%$ were workers, $14.5 \%$ were civil servants, $3.5 \%$ were retired, $24.7 \%$ were students, $15.9 \%$ were artisan, $16.3 \%$ were self-employed, $11.9 \%$ were managers, $8.8 \%$ were others.

Table 6: Monthly expenditure the athletes make for their respective branches

\begin{tabular}{|l|l|l|}
\hline $\begin{array}{l}\text { Monthly } \\
\text { expenditure }\end{array}$ & $\mathbf{N}$ & $\mathbf{\%}$ \\
\hline $100-500 \mathrm{TL}$ & 49 & 21.6 \\
\hline $501-1000 \mathrm{TL}$ & 69 & 30.4 \\
\hline $1001-1500 \mathrm{TL}$ & 53 & 23.3 \\
\hline 1501-2000 TL & 35 & 15.4 \\
\hline 2001-2500 TL & 16 & 7.0 \\
\hline 2501 TL and more & 5 & 2.2 \\
\hline TOTAL & $\mathbf{2 2 7}$ & $\mathbf{1 0 0}$ \\
\hline
\end{tabular}

Examining the sample group's distribution on the basis of the monthly expenditure the athletes make for their branches shows that while 21.6\% (49) of the participants spend between 100 and 500 TL, 30.4\% (69) spend between 501 and 1000 TL, 23.3\% (53) spend between 1001 and 
Ceylan, M., Altıparmak, E., \& Akçakoyun, F. (2015). Examination of Turkish extreme athletes' personality traits in terms of gender and some demographic factors. International Journal of Human Sciences, 12(2), 502-512. doi:10.14687/ijhs.v12i2.3310

1500 TL, 15.4\% (35) spend between 1501 and 2000 TL, 7.0\% (16) spend between 2001 and 2500 TL and 2.2\% (5) spend 2501 TL or more every month.

Table 7: Athletes' distribution by monthly income of their household

\begin{tabular}{|l|l|l|}
\hline $\begin{array}{l}\text { Monthly household } \\
\text { income }\end{array}$ & $\mathbf{N}$ & $\mathbf{\%}$ \\
\hline 1000 TL and less & 19 & 8.4 \\
\hline $1001-2000$ TL & 26 & 11.5 \\
\hline 2001-3000 TL & 44 & 19.4 \\
\hline $3001-4000$ TL & 54 & 23.8 \\
\hline $4001-5000$ TL & 45 & 19.8 \\
\hline 5000 TL and more & 39 & 17.2 \\
\hline TOTAL & $\mathbf{2 2 7}$ & $\mathbf{1 0 0}$ \\
\hline
\end{tabular}

Examining the sample group's distribution by the level of monthly income of the participants' household showed that while the income of $8.4 \%$ (19) of the participants is equal to and less than 1000 TL, that of 11.5\% (26) is between 1001 and 2000 TL, 19.4\% (44) is between 2001 and 3000 TL, 23.8\% (54) is between 3001 and 4000 TL, 17.2\% (45) is between 4001 and 5000 TL and the income of $17.2 \%$ (39) is equal to or more than 5000 TL.

Table 8: Athletes' distribution by sports branches

\begin{tabular}{|l|l|l|l|l|}
\hline \multirow{2}{*}{ Sports branches } & \multicolumn{2}{|c|}{ N } & \multicolumn{2}{c|}{ \% } \\
\cline { 2 - 5 } & Female & Male & Female & Male \\
\hline Kiteboarding & 26 & 29 & 11.4 & 12.8 \\
\hline Windsurfing & 10 & 16 & 4.4 & 7.1 \\
\hline Paragliding & 2 & 15 & 0.8 & 6.7 \\
\hline Free-diving & 9 & 10 & 3.9 & 4.5 \\
\hline Snowboarding & 13 & 22 & 5.7 & 9.7 \\
\hline Snowkiting & 13 & 15 & 5.7 & 6.6 \\
\hline Rock climbing & 3 & 11 & 1.3 & 4.9 \\
\hline Rafting & 3 & 8 & 1.3 & 3.5 \\
\hline River kayaking & 2 & 8 & 0.8 & 3.6 \\
\hline Mountain biking & 5 & 7 & 2.2 & 3.1 \\
\hline TOTAL & 86 & 141 & 37.5 & 62.5 \\
\hline GRAND TOTAL & & 227 & \multicolumn{2}{c|}{100} \\
\hline
\end{tabular}


Ceylan, M., Altıparmak, E., \& Akçakoyun, F. (2015). Examination of 'Turkish extreme athletes' personality traits in terms of gender and some demographic factors. International Journal of Human Sciences, 12(2), 502-512. doi:10.14687/ijhs.v12i2.3310

Examining the distribution of the sample group by the participants' branches showed that while $24.2 \%$ (55) of the athletes are engaged in kiteboarding, $11.5 \%$ (26) are engaged in windsurfing, 7.5\% (17) are engaged in paragliding, 8.4\% (19) are engaged in free diving, $15.4 \%$ (35) are engaged in snowboarding, $12.3 \%$ (28) are engaged in snowkiting, 6.2\% (14) are engaged in rock climbing, 4.8\% (11) are engaged in rafting, 4.4\% (10) are engaged in river kayaking and 5.3\% (12) are engaged in mountain biking.

Table 9: Comparison of the five factor personality dimensions in terms of gender

\begin{tabular}{|l|l|l|l|l|l|l|}
\hline Personality Dimensions & Gender & $\mathbf{N}$ & Average & $\begin{array}{l}\text { Standard } \\
\text { deviation }\end{array}$ & $\mathbf{T}$ & $\mathbf{P}$ \\
\hline Extraversion & Female & 86 & 2.14 & .35 & -2.082 & $.039 *$ \\
& Male & 141 & 2.24 & .31 & & \\
\hline Agreeableness & Female & 86 & 2.12 & .40 & -.088 & .930 \\
& Male & 141 & 2.12 & .35 & & \\
\hline Conscientiousness & Female & 86 & 2.40 & .38 & -1.242 & .216 \\
& Male & 141 & 2.45 & .29 & & \\
\hline \multirow{2}{*}{ Emotional Instability } & Female & 86 & 3.57 & .51 & .856 & .393 \\
& Male & 141 & 3.51 & .49 & & \\
\hline \multirow{2}{*}{ Openness to Experience } & Female & 86 & 2.06 & .36 & -1.638 & .103 \\
& Male & 141 & 2.15 & .41 & & \\
\hline
\end{tabular}

${ }^{*} \mathrm{p}<.05$

In order to examine the difference of Five Factor Personality Scale sub-dimension scores among the male and female sample groups independent samples t- test was used. The significant difference was found in the extraversion trait. The findings indicate that the male group is more extrovert in comparison with the female sample group.

\section{Discussion and Conclusion}

The researches about the extreme sports show different results. Kajtna et al (2004), stated in their research about extreme sports people that extreme sports people have higher emotional consistency score compared to others who participates other sports or ordinary people who do not practice any sports. According to them the reason of this fact is that higher level sports require emotional stability especially during the difficult training period before contests. Goma i Freixanet 
Ceylan, M., Altıparmak, E., \& Akçakoyun, F. (2015). Examination of Turkish extreme athletes' personality traits in terms of gender and some demographic factors. International Journal of Human Sciences, 12(2), 502-512. doi:10.14687/ijhs.v12i2.3310

(1991), stated in their research that risky sports performers have high self control and are dependent to social rules. On the other hand, in the study conducted by Rauter (2011), it is reported that in comparison to females, male athletes take stronger reinforcers concerning orientation for success and therefore are more confident than female athletes concerning sportive skills.

In this research, a total of 227 athletes (86 female, 141 male) that either compete in or trains to participate in a future contest in windsurfing, kitesurfing, snowboarding, snowkiting, river kayaking, rock climbing, free diving, rafting, mountain biking or paragliding participated to the study that has been conducted for the purpose of examining the personality traits of extreme athletes (table 1). While $62.1 \%$ of the participants were male athletes, $37.9 \%$ were female athletes and $52 \%$ of the participants were single (table 2 ).

The question inquiring how the athletes follow news concerning their branches was mostly answered the internet (59.5\%) which was followed by TV (21\%) (table 3). Considering from this perspective, it is understood that visual extreme sports enthusiasts media is very important for extreme sports enthusiasts for following the developments and news of the branches they are into, as well as learning about new branches of extreme sports. It was observed that the least used sources of information concerning the branches are newspapers $(0.9 \%)$ and books $(2.2 \%)$. This is believed to be a consequence of the lack of adequate sources concerning extreme sports in Turkey.

Examining the educational level of the participants showed that extreme athletes tend to have a quite high educational level, and the majority of $52 \%$ had either associate or bachelors' degree (table 4). In the study conducted by Sonmez (2006), on windsurfers, it was demonstrated that the educational level of windsurf enthusiasts is high. This finding is in parallel with the related result found in our study. It is believed that extreme sports, which are known to require high levels of technique, theoretical knowledge and skill, accordingly fall into the area of interest of athletes with rather high level of education.

The distribution of participants according to their profession shows that the largest proportion with $24.7 \%$ of the participants constitutes students (table 5). In the study of Campbell and Johnson (2005), conducted on the developing branches of sports in the United Kingdom, the authors reported that while five percent of the young population is actively involved in at least one branch of extreme sports, twelve percent state their desire to be involved in any branch of extreme sports. In the case of the USA, on the other hand, participation to these sports branches increased by $244.7 \%$ from 1978 to 2000 . While the exact number of extreme sports participants in Turkey is not known, it is an observable fact that the number increases day by day. Liberman (2004), states 
Ceylan, M., Altıparmak, E., \& Akçakoyun, F. (2015). Examination of Turkish extreme athletes' personality traits in terms of gender and some demographic factors. International Journal of Human Sciences, 12(2), 502-512. doi:10.14687/ijhs.v12i2.3310

that today extreme sports are very popular among the members of the "Y" (young) generation, and that the members of the "Y" generation have varying ages from 14 to 25 (8). In addition, Roth states that seeking excitement is a tendency more apparent in men than women, that it starts to increase between the ages of nine and fourteen, reaches its maximum at late puberty (mid-twenties) and after that decreases in line with the increasing age. The fact that $24.7 \%$ of the individuals who participated in our study were students supports these studies. In other words, it is observed that extreme sports gain more popularity among the youth also in Turkey. The interest youngsters have towards new things also applies to extreme sports and the sense of excitement and new experiences motivate youngsters to be involved in extreme sports.

Examining the Five Factor Personality scale in consideration of the participants' gender, it was observed that male participants exhibit a higher rate of extraversion in comparison to females. Extraversion consists of personality traits of being energetic, talkative, amiable, excited, eager and social. Individuals with high level of extraversion are considered to be able to establish relations with others easily, fond of being with others, inclined to cooperation and sympathetic. On the other hand, individuals with low level of extraversion, or in other words introvert individuals, are considered to be withdrawn, not fond of socializing, distant from others, tending to remain silent, shy and timid (Ryan and Deci, 2000). Koruc reports that athletes are mostly extrovert, adventurous, capable of taking risks and responsibility, prescriptive, obedient, usually strict, emotionally stable and fond of living socially. On the other hand, in the study conducted by Rauter (2011), it is reported that in comparison to females, male athletes take stronger reinforcers concerning orientation for success and therefore are more confident than female athletes concerning sportive skills. Dokmen (1997) states that in Turkey extrovert personality of men is supported also by the society, and that while men are directed to coarser motor skills, being more enterprising and impulsive while women are directed towards finer motor skills and being more gentle. In addition, according to Lupton (1998) the personality and emotionality of men and women also emerge in relation with the emotional characters associated with gender roles by the society. This finding obtained in our study suggest that, in an essentially male-dominant society, the higher level of pressure women are subjected to in social, economic, cultural and psychological terms and the difficulties and pressure they experience in the working life are significant factors for women to be more introvert. Therefore, tending towards extreme sports that offer an unusual and exciting experience in terms of socializing and realizing themselves is considered to be a reasonable result for women. 
Ceylan, M., Altıparmak, E., \& Akçakoyun, F. (2015). Examination of Turkish extreme athletes' personality traits in terms of gender and some demographic factors. International Journal of Human Sciences, 12(2), 502-512. doi:10.14687/ijhs.v12i2.3310

Within the scope of the study also comparisons were made between the sub dimensions of the five factor personality traits and the branches of extreme sports, yet the obtained results showed that there are no significant differences among them.

Extreme sports that develop rather rapidly in Turkey and the fact that interest for these sports grows everyday also put the related federations into action and enabled them to initiate the works to raise athletes. Considering from this perspective, conducting further studies on extreme sports and extreme athletes becomes a necessity. The present study is considered to be important in terms of being a source for the future studies to be conducted and for the creation of the literature concerned with extreme sports.

\section{References}

Campbell, D., Johnson, E.; “If it can't kill you, it just isn't sporting”, Observer, 27 March, p. 6, 2005

Dokmen, Z., "Working, gender and gender roles and releation between housework and depression". Turkish Psychology J. 12(39): 39-56

Eren, E., "Yönetim Psikolojisi (3. Baskı)", İstanbul: IU İşletme Fak. İşletme İktisadı Ens. Yay. No. 105,1995

Goma i Freixanet, m., "Personality profile of subjects engaged in high risk sports", Personality and İndividual Differences, 1991, 12 (10), 1087-1093

Kajtna, T., Tusak, M., Baric, R. and Burnik, S., "Personality in bigh risk sports atbletes", Kinesiology, 2004, 36, 1:24-34

Lieberman, D.E., Bramble D.M., "Endurance running and the evolution of Homo", Nature 432:345-352, 2004

Lupton, Deborah. The Emotional Self. London: Sage. 1998

Rauter, S., Doupona Topič, M., "Perspectives Of The Sport-Orented Public In Slovena On Extreme Sports". Kinesiology, 43,1:82-90,2011

Ryan, R.M. and Deci, E.L., "Intrinsic and extrinsic motivations: classic definitions and new directions". Contemporary Educational Psychology 25, pp:54-67, 2000

Somer, O., Korkmaz, M., Tatar, A., "Kuramdan Uygulamaya Beş Faktör Kişilik. Modeli ve Beş Faktör Kişilik Envanteri (5FKE)”, İzmir, Ege Üniversitesi Yayınları, s.1, 13-28, 47-49, 2004

Sönmez, U., "Rü̈gâr Sörfünün Yaylması Açısindan, Sörf Tüketicisinin Profilinin Belirlenmesi Ve Sörf Okullarmm Önemi” Yüksek Lisans Tezi 2006

Şimşek, K.Y. "Dünya Spor Endüstrisinde Ekstrem Sporlarn Gelişimi ve Yeri”, CBÜ Beden Eğitimi Ve Spor Bilimleri Dergisi, Cilt 5, Say1 1 (2010)

Şimşek, K.Y., "Ekestrem Ve Geleneksel Spor Katılmmolar Arasinda Duygu Arama Farklilkklarmm Karşılaştırlmasi”, Niğde Üniversitesi Beden Eğitimi Ve Spor Bilimleri Dergisi Cilt 5, Sayı 2, 2011 
Ceylan, M., Altıparmak, E., \& Akçakoyun, F. (2015). Examination of Turkish extreme athletes' personality traits in terms of gender and some demographic factors. International Journal of Human Sciences, 12(2), 502-512. doi:10.14687/ijhs.v12i2.3310

\section{Türk Ekstrem Sporcuların Kişilik Özelliklerinin Cinsiyete ve Bazı Demografik Özelliklere Göre İncelenmesi}

\section{Özet}

$\mathrm{Bu}$ araştırma, ekstrem sporcuların kişilik özelliklerinin incelemesi amacıyla yapılmıştır. Bu amaç doğrultusunda araştırmaya, yargısal örnekleme yöntemiyle seçilmiş, snowboard, snowkite, uçurtma sörfü, rüzgar sörfü, akarsu ve nehir kanosu, dă̆ bisikleti, serbest dalış, yamaç paraşütü, kaya tırmanışı ve rafting branşlarında yarışmacı olan ya da bir yarışmaya katılmak için hazırlık yapan, 86'sı kadın, 141'i erkek olmak üzere 227 ekstrem sporcu katılmıştır. Anket uygulamaları, ülke genelinde bulunan ekstrem spor tesislerinde gerçekleştirilmiştir.

Araştırmada veri toplamak amacıyla Somer, Korkmaz ve Tatar tarafindan geliştirilen beş faktör kişilik envanterinin 85 sorudan oluşan kısa forumu kullanılmıştır. Elde edilen veriler SPSS programında kaydedilmiş, frekans, yüzde, aritmetik ortalama, standart sapma değerleri hesaplanmış ve cinsiyetler arası farklılığı bulmak için “independent samples t- test” kullanılarak yorumlanmışıtır.

Elde edilen bulgular incelendiğinde, erkek sporcuların erkek sporcuların kadın sporculara oranla daha yüksek dışa dönük özellik gösterdiği görülmektedir $(\mathrm{p}<0.05)$. Sonuç olarak; temelde erkek egemen bir toplumda, sosyal, ekonomik, kültürel ve psikolojik anlamda kadının daha çok baskıya maruz kalması, sosyal hayatında üstelendiği roller, iş hayatında karşılaşılan zorluk ve baskıların bir sonucu olarak, daha içe kapanık bir yapıya sahip olmalarında önemli bir etken olduğunu düşündürmektedir.

Anahtar Kelimeler: Ekstrem Spor; Ekstrem Sporcu; Kişilik. 